\title{
KARAKTERISTIK ORIENTASI RUMAH TRADISIONAL BUGIS (BOLA UGI) DI DUSUN KAJUARA KABUPATEN BONE SULAWESI SELATAN
}

\author{
Hamka $^{1}$, Antariksa ${ }^{2}$, Lisa Dwi Wulandari ${ }^{3}$ \\ ${ }^{1}$ Mahasiswa Program Magister Arsitektur Lingkungan Binaan Universitas Brawijaya \\ ${ }^{2,3}$ Dosen Program Magister Arsitektur Lingkungan Binaan Universitas Brawijaya \\ hamkahamzah_07@yahoo.co.id ${ }^{1}$, mr.antariksa@gmail.com ${ }^{2}$, lisaromansya@yahoo.co.uk ${ }^{3}$
}

\begin{abstract}
Abstrak
Permukiman tradisional identik dengan tradisi dan budaya masyarakat setempat di masingmasing daerah. Permukiman tradisional umumnya memiliki aturan terhadap pola dan tatanan rumah pada permukimannya sesuai dengan tradisi dan budaya setempat, salah satunya dalam hal orientasi rumah. Pola dan tatanan orientasi rumah tersebut juga terdapat pada permukiman di Dusun Kajuara, namun orientasi bola ugi yang ada di dusun ini memiliki karakteristik yang beragam. Dusun Kajuara merupakan permukiman yang berada di wilayah topografi perbukitan, namun sebagian dari wilayah permukimannya berada pada kondisi tanah datar. Pola permukiman di dusun ini umumnya berpola linier membentuk kelompok-kelompok permukiman yang mengikuti sirkulasi jalan desa. Tujuan penelitian ini adalah untuk mengetahui dan menjelaskan karakakteristik orientasi bola ugi di Dusun Kajuara yang memiliki arah orientasi rumah yang beragam, berdasarkan pendekatan aturan adat dan tradisi masyarakat setempat. Metodelogi penelitian menggunakan metode kualitatif analisis deskriptif dengan teknik analisis komparatif terhadap beberapa kelompok permukiman. Hasil penelitian terhadap kelompok permukiman tersebut menunjukkan bahwa dasar munculnya orientasi bola ugi yang beragam adalah terkait dengan konsep orientasi rumah dapat menghadap ke arah empat penjuru mata angin. Arah orientasi rumah yang baik adalah menghadap timur dan barat dengan mempertimbangkan kondisi topografi letak rumah. Rumah yang berada pada topografi perbukitan umumnya akan berorientasi kearah tanah yang lebih tinggi, sedangkan yang berada pada kondisi tanah datar umumnya akan berorientasi ke jalan.
\end{abstract}

Kata kunci: Rumah tradisional Bugis, orientasi rumah Bugis, permukiman tradisional

\begin{abstract}
Traditional settlements are identical with tradition and cultural of local communities in each region. Traditional settlements generally have the rules in the pattern and order of houses in accordance with the traditions and culture. One of the considerations is the orientation of the houses. The orientation pattern and order of the houses can be found on settlements of Kajuara Village, however, the orientation of bola ugi in this village has diverse characteristics. Kajuara Village is a settlement in the area of hilly topography, but most of the territory of the settlement are on the flat ground conditions. The pattern of settlement in this village generally has linear patterned which formed groups of settlements followed the circulation path. The purpose of this study was to determine and explain the characteristics of orientation bola ugi in Kajuara Village which has a diverse of houses orientation. The condition based on customs rules and traditions of the local community. The research methodology used qualitative descriptive analysis with comparative technique. The results showed that the diversity of bola ugi orientation is associated with the houses
\end{abstract}


orientation concept, which can be facing four directions of cardinal directions. The best direction of houses is by facing east and west and by considering the condition topography. Houses that located on hilly topography generally oriented towards higher ground, while those in the flat ground conditions generally will be oriented to the street.

\section{Keywords: Bugis traditional house, orientation of Bugis House, traditional settlement}

\section{Pendahuluan}

Dusun Kajuara merupakan sebuah wilayah permukiman petani Suku Bugis yang berada di Desa Mulamenre'e, Kec. Ulaweng, Kabupaten Bone, Sulawesi Selatan dan terletak $11 \mathrm{Km}$ dari ibukota kecamatan, sekitar $40 \mathrm{Km}$ dari Kota Bone. Permukiman Suku Bugis umumnya mengelompok padat dan menyebar. Pola mengelompok banyak terdapat di dataran rendah, dekat persawahan, pinggir laut, dan danau, sedangkan pola menyebar banyak terdapat di pegunungan atau perkebunan, selain juga dibedakan berdasarkan tempat pekerjaan, yaitu: pallaon ruma (kampung petani), pakkaja (kampung nelayan), matowa (kepala kampung), (Hasan, \& Prabowo, 2002).Berdasarkan letak geografis dan kondisi topografi tanahnya, Dusun Kajuara berada di wilayah perbukitan dan pola permukimannya cenderung menyebar membentuk kelompok-kelompok permukiman yang terhubung secara linier oleh sirkulasi jalan desa yang melintasi Dusun Kajuara. Terdapat 5 kelompok permukiman atau perkampungan di Dusun Kajuara yang masing-masing memiliki karakteristik orientasi. Orientasi bola ugi dalam tata lingkungan permukiman di Dusun Kajuara ini menunjukkan arah orientasi rumah yang beragam, sehingga menarik untuk diteliti lebih lanjut.

Orientasi rumah bagi masyarakat tradisional sangat penting dan disakralkan, ada beberapa unsur yang sering digunakan sebagai patokan arah orientasi rumah tradisional adalah matahari, gunung, sungai, laut, dan arah angin, (Idawarni, 2011). Rumah dan lingkungan permukiman di Dusun Kajuara merupakan salah satu produk budaya masyarakat tradisional yang tentunya memiliki pengetahuan seperti halnya mengenai orientasi rumah. Ruang tempat tinggal manusia senantiasa memiliki pola dan struktur tertentu untuk setiap budaya, waktu, dan tempat, (Rapoport dalam Wikantiri et al, 2011). Orientasi rumah pada permukiman tradisional dapat dipengaruhi oleh faktor pandangan kosmologi masyarakatnya. Salah satu contoh rumah tradisional yang memiliki kosmologi terhadap orientasi adalah Rumah Tongkonan Toraja yang polanya berderet dari timur ke barat. Dalam kosmologi dari aluk todolo arah matahari tenggelam (barat) dipandang tempat bersemayam arwah leluhur sebagai arah kematian dan masa lampau dan arah matahari terbit (timur) dipandang sebagai arah kelahiran sebagai masa depan (Sumalyo, 2001). Dasar pola permukiman Toraja mengikuti pola orientasi matallo-mattampu (timur-barat) dengan pengaturan tongkonan menghadap utara dan alang menghadap selatan yang saling berhadapan dan mebentuk spasial diantaranya, konsep ini bersumber dari ajaran kosmologi aluk todolo (Mithen \& Onesimus, 2003).

Penentuan orientasi rumah juga terkait dengan kepercayaan masyarakatnya terhadap suatu hal yang penting seperti pada orientasi rumah di permukiman nelayan Dusun Salarang Kabupaten Maros yang berorientasi ke arah timur dipengaruhi oleh faktor budaya khususnya kepercayaan terhadap tanah leluhur sebagai daerah asal (Bone), (Wikantiri et al, 2011). Hasil kajian lainnya menunjukkan bahwa penentuan arah dan letak permukiman dan rumah tinggal di Kampung Kanarea Kabupaten Gowa didasari oleh kerpercayaan terhadap aturan adat yang berlaku, dengan mengikuti aturan tersebut dipercaya akan mendatangkan kebaikan dan rezeki yang melimpah, (Idawarni, 2011). Selain itu, penentuan orientasi rumah pada permukiman Suku Bugis juga ada yang mempertimbangkan mata pencaharian khususnya yang berada di daerah pesisir, contohnya pada permukiman Bugis di Kelurahan Mata dan Puunggaloba ini membentuk dua macam pola yaitu linier dan mengelompok. Sungai dan laut selalu dijadikan orientasi rumah, karena latar belakang mata pencaharian masyarakat Bugis yang berkaitan dengan sungai dan laut, (Nurjannah \& Anisa, 2010).

Hal. 95. Langkau Betang, Vol.2, No.2, 2015 
Orientasi rumah Suku Bugis umumnya berorientasi pada empat penjuru mata angin dengan dasar pertimbangan adanya kepercayaan bahwa mereka tidak boleh membelakangi sumber kehidupan, untuk menghindari angin jahat (arah utara dan selatan) dan ke arah sumber mata pencaharian pokok, (Mufti radja dalam Nurjannah \& Anisa, 2010). Dari segi bentukan ruang rumah Bugis dipengaruhi oleh filosofi sulapa eppa. Istilah sulapa eppa merupakan falsafah pandangan hidup masyarakat Suku Bugis yang berarti persegi empat, yaitu sebuah pandangan dunia empat sisi yang bertujuan untuk mencari kesempurnaan ideal dalam mengenali dan mengatasi kelemahan manusia, (Morrel, 2005).

Penelitian ini menarik untuk dikaji mengenai unsur yang dijadikan patokan utama orientasi rumah beserta maknanya, dan dianalisis untuk mengetahui karakteristik orientasi rumah masyarakat di Dusun Kajuara. Berdasarkan uraian mengenai orientasi rumah dari beberapa kajian yang pernah dilakukan, maka karakteristik orientasi rumah di permukiman Suku Bugis Dusun Kajuara akan dikaji berdasarkan kelompok-kelompok permukiman yang ada di dusun ini, dengan mempertimbangkan karakter kondisi topografi lingkungannya. Mencari konsep arah orientasi berdasarkan kepercayaan adat dan tradisi masyarakat setempat maupun faktor-faktor lainnya, untuk dianalisis sesuai dengan kondisi masing-masing kelompok permukiman. Tujuan akhirnya untuk mengetahui karakakteristik orientasi bola ugi dan faktor-faktor yang menjadi acuan orientasi rumah masyarakat di Dusun Kajuara, berdasarkan pendekatan aturan adat dan tradisi masyarakat setempat.

\section{Metodologi}

Penelitian ini menggunakan metode kualitatif diskriptif analisis untuk membahas dan membandingkan karakteristik orientasi bola ugi yang berada pada beberapa kelompok permukiman di Dusun Kajuara. Penelitian diawali dengan pengumpulan data objek studi dari data observasi, wawancara dan literatur yang terkait dengan topik penelitian. Dari observasi dan wawancara ditemukan bahwa terdapat 5 kelompok permukiman yang ada di Dusun Kajuara. Kelima kelompok permukiman tersebut merupakan RT atau kampung yang menjadi bagian dari Dusun Kajuara, masing-masing memiliki ciri khas pola permukiman dan karakter lingkungan. Beberapa kelompok permukiman berada di topografi tanah yang datar dan yang lainnya diperbukitan. Proses pembahasan diawali dengan penjelasan gambaran umum lokasi penelitian dengan menguraikan karakteristik umum Dusun Kajuara dan masing-masing kelompok permukimannya. Membahas konsep pandangan adat dan tradisi masyarakat terkait orientasi rumah pada permukiman mereka berdasarkan hasil wawancara yang telah dilakukan, dan yang ketiga mengidentifikasi dan menganalisis karakteristik orientasi rumah Bugis yang ada dimasing-masing kelompok permukiman untuk mengetahui perbedaannya. Terakhir adalah merumuskan kesimpulan akhir dari hasil pembahasan mengenai karakteristik orientasi bola ugi yang ada di Dusun Kajuara.

\section{Hasil dan Pembahasan Gambaran Lokasi}

Lokasi penelitian berada di Dusun Kajuara, Desa Mulamenre'e, Kecamatan Ulaweng, Kabupaten Bone, Sulawesi Selatan. Lokasi tepatnya adalah rumah-rumah tradisional Bugis yang berada pada pusat-pusat permukiman di sepanjang koridor jalan desa yang melintasi wilayah Dusun Kajuara. Dusun Kajuara merupakan salah satu dusun dari tiga dusun yang terdapat di Desa Mulamenre'e. Secara administrasi Dusun Kajuara merupakan pusat desa atau ibukota Desa Mulamenre'e. Dusun Kajuara ini terdiri dari 5 RT, yaitu RT 1 meliputi (Kampung Paccanring dan La'gangka), RT 2 (Kampung Kampiri), RT 3 (Kampung Cilellang), RT 4 (Kampung Mappenrae), dan RT 5 meliputi (Kampung Kajuara dan Kampung Laleng Bata). RT 5 ini merupakan pusat Dusun Kajuara dan juga menjadi pusat pemerintahan Desa Mulamenre'e. Dusun Kajuara berada di wilayah perbukitan dengan kondisi lingkungan alam yang masih alami berupa perkebunan, sawah, dan hutan (Gambar 1). 


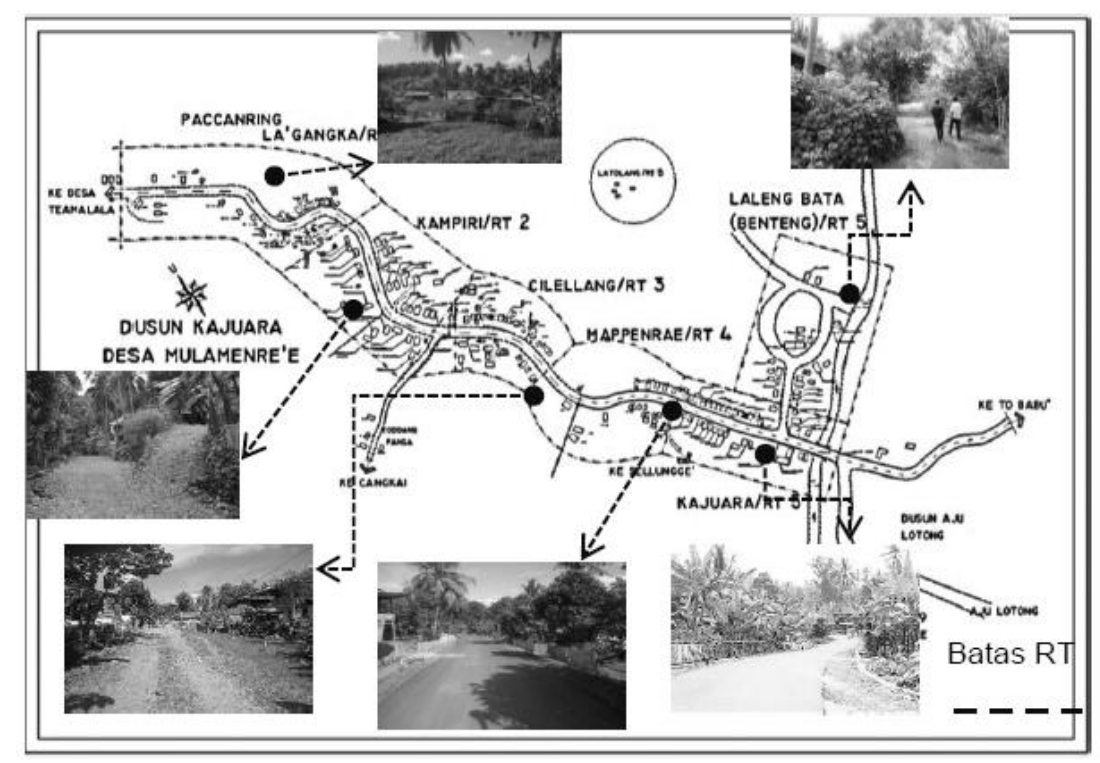

Gambar 1. Gambaran Lokasi Penelitian Dusun Kajuara Sumber: Hasil Penelitian, 2015

Batas Dusun Kajuara sebagai berikut: Utara : Desa Galung, Selatan : Desa Teamusu, Timur : Dusun Ajulotong; dan Barat : Desa Teamalala

\section{Sejarah Lokasi Penelitian}

Sejarah singkat permukiman masyarakat di dusun ini awalnya tinggal menyebar diperbukitan, di ladang, di kebun, atau di sawahnya masing-masing dan belum ada jalan desa yang melintas di wilayah ini. Pada awalnya Dusun Kajuara merupakan sebuah wilayah yang dipimpin oleh seorang Arung (bangsawan) yang dikenal dengan Sulewatang Kajuara. Hingga masuk zaman pasca kemerdekaan, terjadilah suatu pemberontakan yang dikenal dengan istilah zaman gorilla dan mengharuskan masyarakat mengungsi ke desa-desa tetangga, karena Dusun Kajuara yang berada diperbukitan menjadi salah-satu wilayah perang antara tentara melawan pemberontak pejuang gorilla. Setelah kondisi aman, barulah mereka kembali ke desa ini lagi, dan dengan dibuatnya sarana jalan desa oleh pemerintah, maka masyarakat yang tinggal di kebun atau sawah diperintahkan untuk pindah bermukim di lokasi yang mendekati sarana jalan tersebut. Dari peristiwa tersebut maka muncullah nama Desa Mulamenre'e yang berarti (awal mula) naik kembali bermukim dengan Dusun Kajuara sebagai ibukota desa.

Nama dari tiap wilayah RT memiliki arti masing-masing berdasarkan sejarah cerita rakyat setempat. RT 5 (Kampung Kajuara dan Lalengbata), penamaan Kajuara berasal dari kata ajjuarang yang berarti orang yang di taati atau dipatuhi, karena di Kajuara ini dulunya ada orang yang dianggap tetua adat maka diberilah nama Kajuara, sedangkan Lalengbata berarti di dalam batu, sebab kampung ini berada di dalam lingkaran benteng yang terbuat dari susunan batu, di dalamnya terdapat situs tana bangkalae, yaitu tempat tersimpannya gabungan tanah dari tiga kerajaan besar yang ada di Sulawesi Selatan (Kerajaan Bone, Luwu, dan Gowa) sebagai simbol perdamaian antara ketiga kerajaan tersebut. Tana' bangkala'e yang ada di Dusun Kajuara merupakan salah satu dari beberapa situs sejenis yang ada di Kabupaten Bone dan situs ini digunakan sebagai tempat melakukan ritual adat tertentu oleh masyarakat setempat ataupun pengunjung yang berasal dari luar dusun (Gambar 2). 


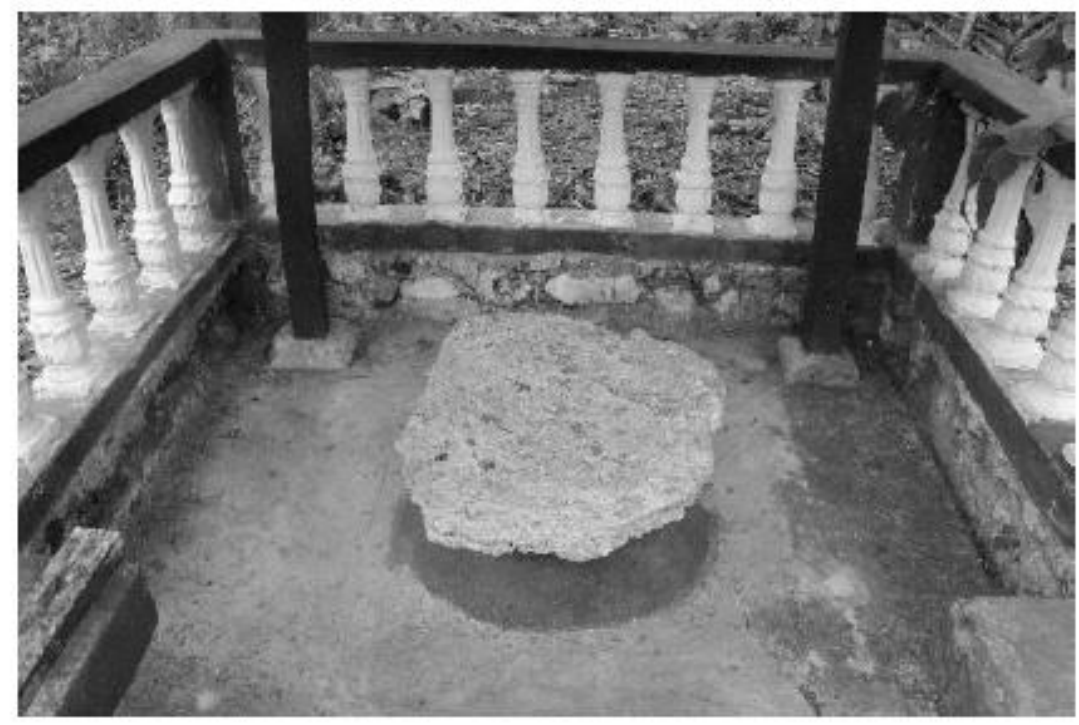

Gambar 2. Situs Tana Bangkala'e

Sumber: Dokumentasi, 2015

RT 4 Kampung Mappenrae berarti memperbaiki, RT 3 Kampung Cilellang yang berarti satu karena di kampung ini dulunya hanya ada satu unit rumah saja, RT 2 Kampung Kampiri yang berasal dari kata mampiri yang berarti penjaga atau penunggu, karena dulunya ada orang yang dianggap sebagai penunggu kampung. RT 1 La' gangka yang berasal dari kata gangkangnna yang berarti batas, sebab kampung ini merupakan batas wilayah Dusun Kajuara dengan desa tetangga, sedangkan Paccanring berarti kekasih, masyarakat menganggap bahwa dulu tempat ini merupakan tempat untuk mencari kekasih dari desa tetangga.

\section{Konsep Orientasi}

Berdasarkan pada hasil wawancara dengan beberapa sanro bola (dukun rumah) di Dusun Kajuara ditemukan bahwa, secara umum bola ugi dapat berorientasi ke empat penjuru mata angin, yaitu timur, barat, utara dan selatan, namun orientasi rumah terbaik dan dianjurkan menghadap ke arah timur dan barat. Orientasi timur merupakan arah terbitnya matahari, dalam hal ini rumah yang berorientasi ke timur akan memiliki rezeki yang melimpah, sedangkan orientasi ke barat merupakan arah kiblat menuju kabbah, rumah yang beorientasi ke barat dipercaya akan mendatangkan keselamatan dunia akhirat.

Orientasi ke arah utara dan selatan dianjurkan jika menyesuaikan dengan kondisi topografi tanah letak rumah yang berada di perbukitan, sebab rumah yang berada di perbukitan akan menghadap kearah tanah yang lebih tinggi yaitu pegunungan, karena secara pandangan kosmologi pegunungan dianggap sebagai dunia atas/bagian kepala (tempat baik dan suci). Selain itu, gunung merupakan tempat masyarakat di dusun ini mencari nafkah sebagai petani, sehingga hal tersebut menjadi bentuk penghargaan terhadap pegunungan yang telah menjadi sumber kehidupan. Maka orientasi rumah yang berada diperbukitan dianjurkan menghadap ke arah tanah yang lebih tinggi, sedangkan rumah yang berada pada kondisi tanah yang datar sebaikya mempertimbangkan orientasi timur dan barat. Konsep tersebut menunjukkan bahwa orientasi rumah dapat menghadap ke arah timur, barat, utara, dan selatan dengan mempertimbangkan unsur-unsur kepercayaan dan lingkungan (Gambar 3). 


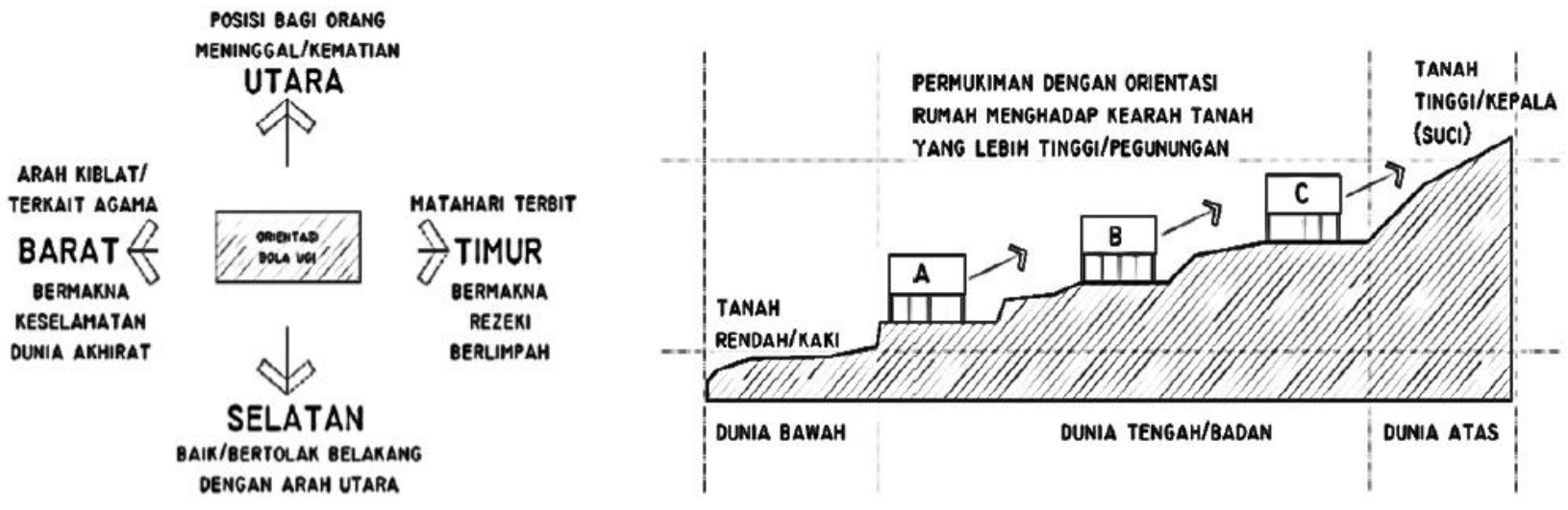

Gambar 3. Konsep Orientasi Bola Ugi di Dusun Kajuara

Sumber: Hasil Analisa, 2015

\section{Orientasi di RT 1 Kampung Paccanring dan Lagangka}

RT 1 ini meliputi Kampung Paccanring dan La' gangka, Kampung ini terbagi menjadi dua berdasarkan kondisi topografi tanahnya, yaitu diperbukitan dan tanah datar. Pola permukimannya terbagi menjadi dua, yaitu pola menyebar di Kampung Paccanring dan pola mengelompok di Kampung La' gangka. Orientasi rumah dikedua kampung ini secara umum terpengaruh dengah keberadaan dari sirkulasi jalan, sehingga secara arah hadap rumah terdapat dua jenis tipe rumah, yaitu bola mangolo (rumah menghadap ke jalan) dan bola mpare' (rumah yang letaknya sejajar dengan jalan). Karakteristik orientasi rumah di RT 1 ini memiliki beberapa jenis tipe arah orientasi rumah, (Gambar 4).

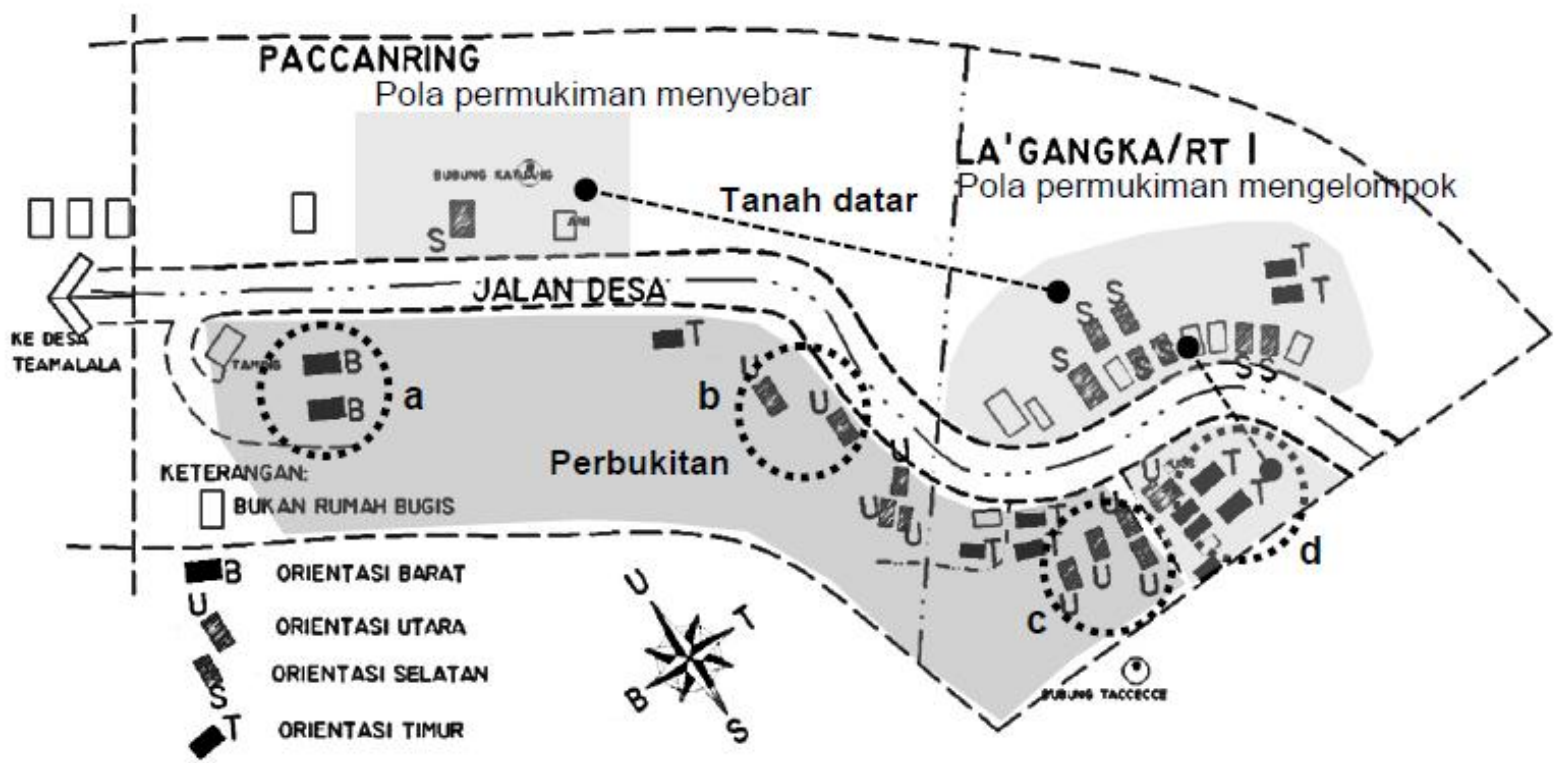

Gambar 4. Karakteristik Orientasi Bola Ugi di Permukiman RT 1 Sumber: Hasil Analisa, 2015 
Orientasi rumah di kampung ini dipengaruhi oleh sirkulasi jalan yang melintas dari timur ke barat, khususnya orientasi rumah yang berada di Kampung La' gangka. Orientasi rumah cenderung mengarah ke utara dan selatan yang berhadapan dengan jalan, namun masih terdapat beberapa rumah yang berorientasi ke timur ataupun barat. Orientasi rumah yang berada di sebelah utara jalan secara umum berorientasi ke jalan (selatan). Rumah yang berada di sebelah selatan jalan memiliki pola orientasi yang lebih beragam, ada yang berorientasi ke jalan (utara), timur, dan barat. Beberapa diantaranya mengorientasikan rumah menghadap ke arah topografi tanah yang lebih tinggi, dan terdapat juga orientasi rumah yang sebaliknya, yaitu mengarah ke arah tanah lebih rendah yang menghadap langsung ke jalan, karena menjadikan jalan sebagai pusat orientasi (Gambar 5)
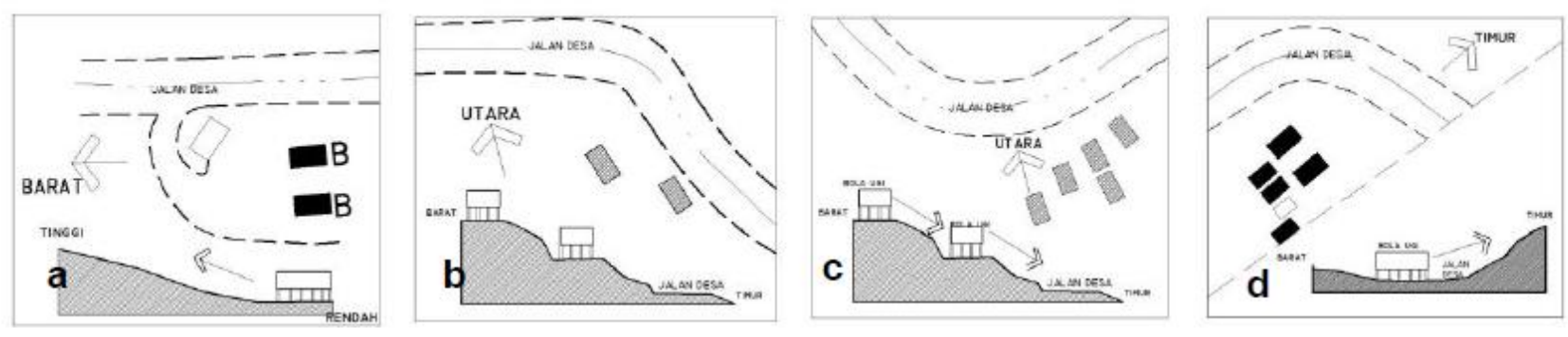

Gambar 5. Orientasi Bola Ugi di sebelah Selatan Jalan RT 1 Sumber: Hasil Analisa, 2015

Pada gambar 5 menunjukkan orientasi bola ugi yang terdapat di sebelah selatan jalan di RT 1, diantara yaitu a merupakan tipe bola mpare' (sejajar jalan) berorientasi ke barat menghadap ke tanah yang lebih tinggi, b merupakan tipe bola mpare' juga, namun orientasinya menghadap ke utara mengikuti jalan, di sebelah timur merupakan jalan yang topografinya lebih rendah, sedangkan di sebelah barat topografinya lebih tinggi. Jadi orientasi tipe ini lebih mempertimbangkan akses sirkulasi rumah ke jalan, c merupakan tipe bola mangolo menghadap ke jalan (utara), orientasi rumah ini mempertimbangkan aksesibiltas ke jalan karena orientasi rumah ini mengarah ke tanah yang lebih rendah yakni kearah jalan, dan d merupakan tipe bola mangolo yang menghadap ke arah jalan (timur), yang merupakan arah terbitnya matahari dan juga di sebelah timur rumah ini juga terdapat perbukitan yang menjadi salah satu patokan arah orientasi rumah. Jadi orientasi rumah secara keseluruhan di RT ini sangat mempertimbangkan posisinya terhadap jalan.

\section{Orientasi di RT 2 Kampung Kampiri}

RT 2 ini meliputi Kampung Kampiri yang berdasarkan kondisi topografi tanahnya berada di perbukitan, tepatnya berada diantara dua perbukitan. Pola permukimannya berbentuk linier mengikuti sirkulasi jalan. Orientasi rumah di kampung ini secara umum menghadap ke arah selatan mengikuti tanah yang lebih tinggi. Rumah di permukiman Kampung Kampiri ini dibagi menjadi dua kelompok, yaitu kelompok yang berada dibagian atas dan lebih banyak berjenis bola mangolo (menghadap ke jalan), sedangkan kelompok yang berada dibagian bawah/ujung (cappa Kampiri) cenderung merupakan jenis bola mpare (sejajar jalan). Meskipun terdapat dua kelompok, secara keseluruhan arah orientasi rumah di Kampung Kampiri ini menghadap ke selatan (ke arah perbukitan), hanya terdapat beberapa rumah yang orientasinya berbeda. Karakteristik orientasi dan pola permukiman rumah di RT 2 Kampung Kampiri, seperti pada (Gambar 6). 


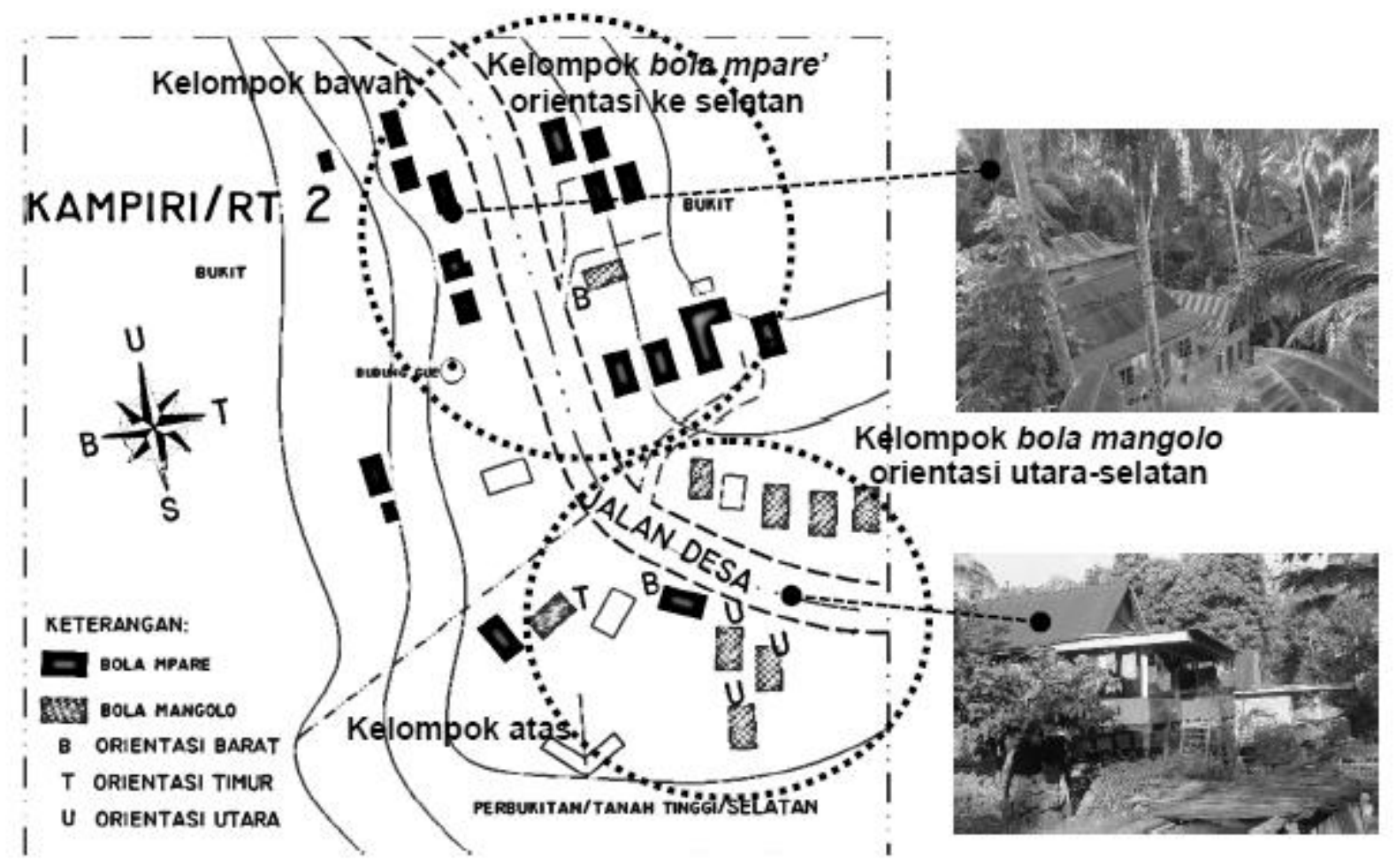

Gambar 6. Karakteristik Orientasai Bola Ugi di RT 2 Sumber: Hasil Analisa, 2015

Gambar 6 menunjukkan bahwa secara keseluruhan orientasi rumah Bugis yang ada di Kampung Kampiri ini didominasi oleh rumah yang berorientasi ke arah selatan (ke arah tanah yang lebih tinggi/perbukitan). Pada bagian kelompok bawah hanya terdapat satu rumah yang menghadap ke jalan (barat) dan letak jalannya lebih rendah dari pada letak rumah, sisanya merupakan rumah mpare' (sejajar jalan) dengan orientasi ke arah selatan. Pada kelompok permukiman bagian atas terdapat beberapa macam orientasi bagi rumah yang berada di sebelah selatan jalan, ada 3 bola ugi yang menghadap ke utara (ke arah jalan) dan ada 1 bola ugi yang menghadap ke barat dan juga ke timur. Rumah yang berada di sebelah utara jalan orientasinya menghadap ke jalan sekaligus ke arah selatan (perbukitan). Jadi secara keseluruhan, orientasi bola ugi yang ada di Kampung Kampiri ini mempertimbangkan kondisi topografi dan arah rumah ke dataran tinggi.

\section{Orientasi di RT 3 Kampung Cilellang}

RT 3 ini merupakan kelompok permukiman Kampung Cilellang dengan kondisi topografi tanahnya berada di wilayah tanah yang datar. Pola permukimannya berbentuk linier mengikuti jalan desa, dan orientasi rumah Bugisnya secara umum berorientasi ke jalan. Rumah tradisional Bugis bola ugi yang ada di wilayah Kampung Cilellang ini pada umumnya menghadap ke jalan (tipe bola mangolo). Pada dasarnya bola ugi merupakan jenis rumah tradisional yang dibangun dengan bentuk memanjang ke belakang. Pola seperti ini menempatkan bagian fasade rumah menghadap langsung ke jalan dan banyak ditemui pada kampung-kampung/permukiman yang memiliki topografi tanah yang datar seperti pada Kampung Cilellang ini. (Gambar 7). 


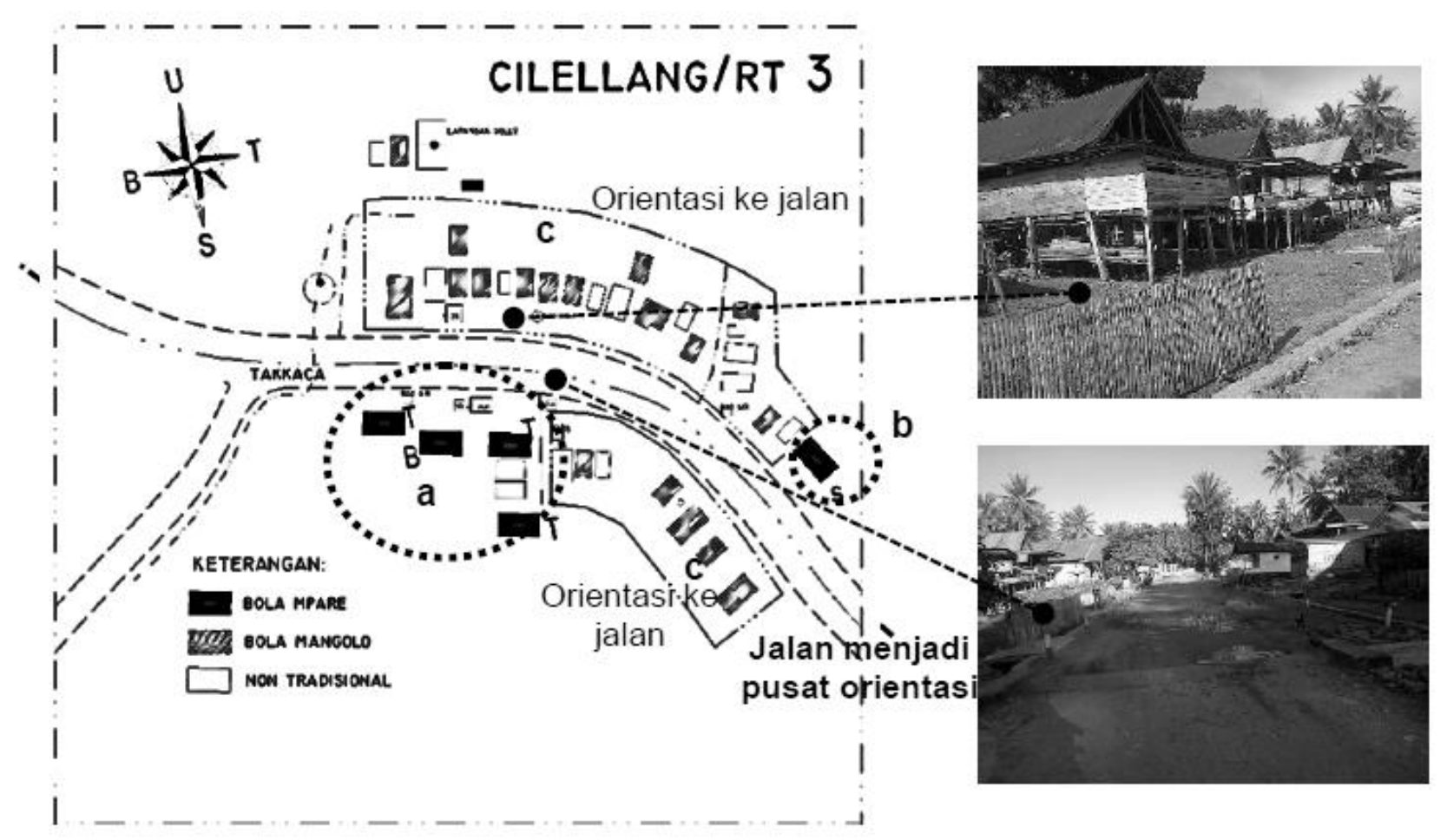

Gambar 7. Karakteristik Orientasai Bola Ugi di RT 3 (Kampung Cilellang)

Sumber: Hasil Analisa, 2015

Karakteristik orientasi bola ugi di Kampung Cilelllang ini menjadikan jalan sebagai pertimbangan utama untuk dijadikan pusat orientasi. Rumah berderet secara linier mengikuti jalan dan rumah berorientasi ke jalan, karena jalan melintas dari arah timur ke barat, maka secara umum rumah akan menghadap ke arah selatan atau utara. Terdapat beberapa rumah yang mempertimbangkan arah orientasi rumah yang baik (timur-barat), seperti pada (Gambar 7) lingkaran a dan b. Lingkaran a terletak di sebelah selatan jalan dan terdapat 3 rumah (bola ugi) yang menghadap ke timur dan 1 rumah yang menghadap ke barat, sedangkan 1 rumah pada lingkaran $\mathbf{b}$ menghadap ke arah selatan karena mengikuti alur sirkulasi jalan.

\section{Orientasi di RT 4 dan RT 5}

Permukiman di RT 4 (Mappenrae) dan RT 5 (Kajuara dan Lalengbata), secara fisik telah menjadi satu kesatuan karena tidak ada lagi ruang pemisah antara kedua RT ini. Tidak seperti RT lainnya yang memiliki ruang antara yang berfungsi sebagai pemisah alami yang membentuk kelompok permukiman di Dusun Kajuara. Rumah yang ada dikedua RT ini tidak lagi didominasi oleh rumah tradisional, karena masyarakat di wilayah ini telah mengganti rumah mereka dengan rumah modern. Topografi tanah kedua RT ini berada di wilayah tanah datar, polanya berbentuk linier mengikuti jalan desa, dan orientasi rumah Bugisnya secara umum berorientasi ke jalan, seperti pada pola permukiman dan orientasi di Kampung Cilellang (Gambar 8). 


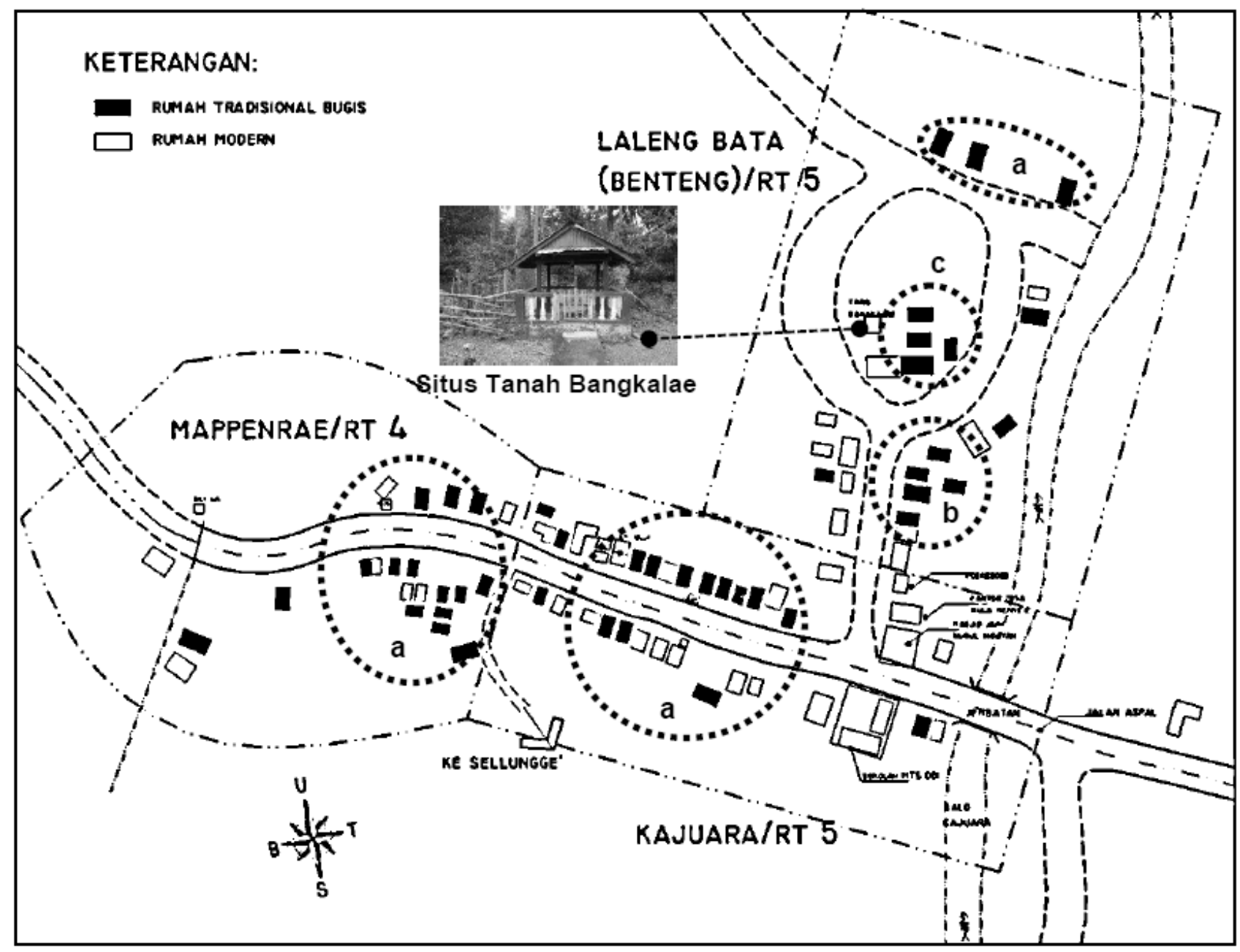

Gambar 8. Karakteristik Orientasai Bola Ugi di RT 4 dan 5 (Kampung Cilellang) Sumber: Hasil Analisa, 2015

Secara umum orientasi rumah menghadap ke arah utara dan selatan dengan pusat orientasi ke jalan seperti pada lingkarang a pada (Gambar 8). Pada bagian lingkaran b menunjukkan bola ugi yang berorientasi ke arah barat dan juga menghadap ke jalan, sedangkan orientasi rumah pada bagian lingkaran c juga menghadap ke arah barat, namun orientasinya mengarah pada situs tana bangkalae yang ada di depannya. Letak rumah pada bagian lingkaran $\mathbf{c}$ ini berada di dalam susunan benteng batu Kampung Laleng Bata. Jadi secara keseluruhan karakteristik orientasi rumah tradisonal Bugis di RT 4 dan RT 5 ini mempertimbangkan letak dan orientasinya terhadap sirkulasi jalan.

\section{Karakteristik Orientasi Rumah Tradisional Bugis di Dusun Kajuara}

Berdasarkan hasil pembahasan dari masing-masing kelompok permukiman yang ada di Dusun Kajuara maka berikut ini beberapa tipe karakteristik orientasi rumah tradisional Bugis yang ada di Dusun Kajuara, yaitu orientasi rumah berdasarkan posisi tata letaknya terhadap jalan, orientasi rumah berdasarkan pertimbangan topografi tanah perbukitan dan jalan, dan orientasi rumah berdasarkan pada kondisi topografi tanah yang datar. Arah orientasi tersebut dipengaruhi oleh beberapa unsur seperti unsur kepercayaan, aksesibilitas sirkulasi, dan kondisi eksisting serta topografi lingkungan. (Gambar 9, 10, dan 11). 

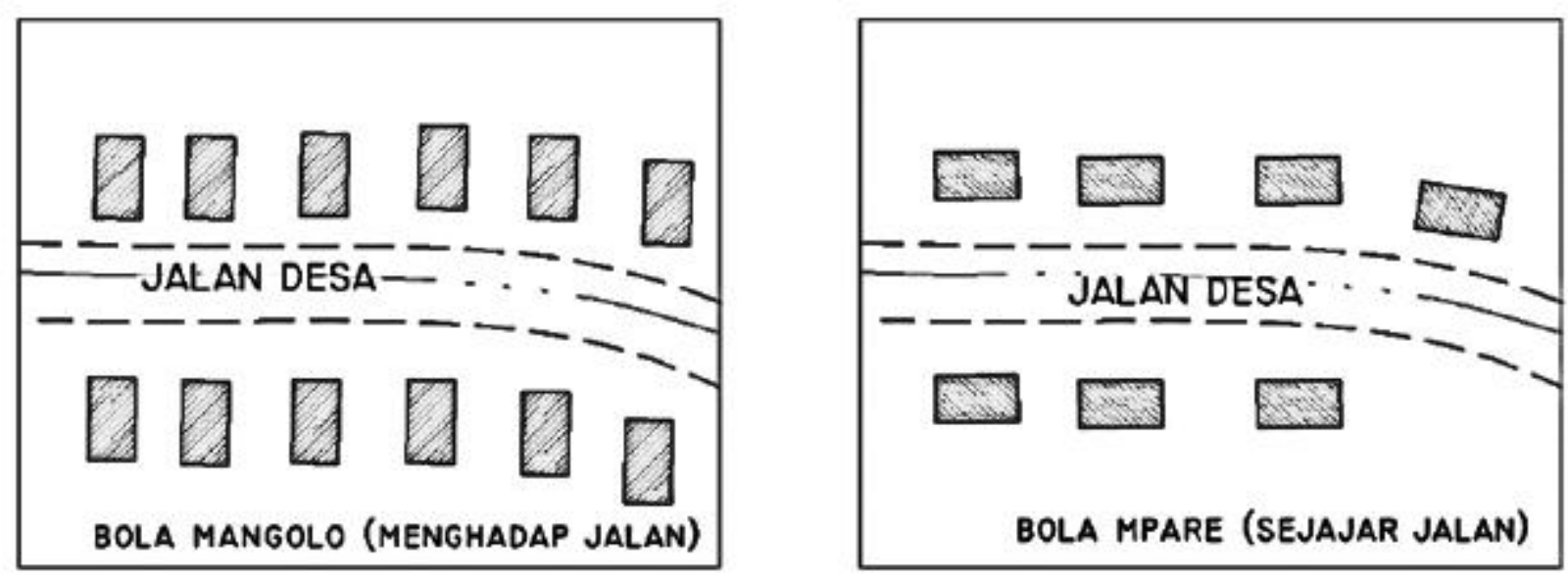

Gambar 9. Orientasi Rumah Berdasarkan Tata Letaknya Terhadap Jalan Sumber: Hasil Analisa, 2015

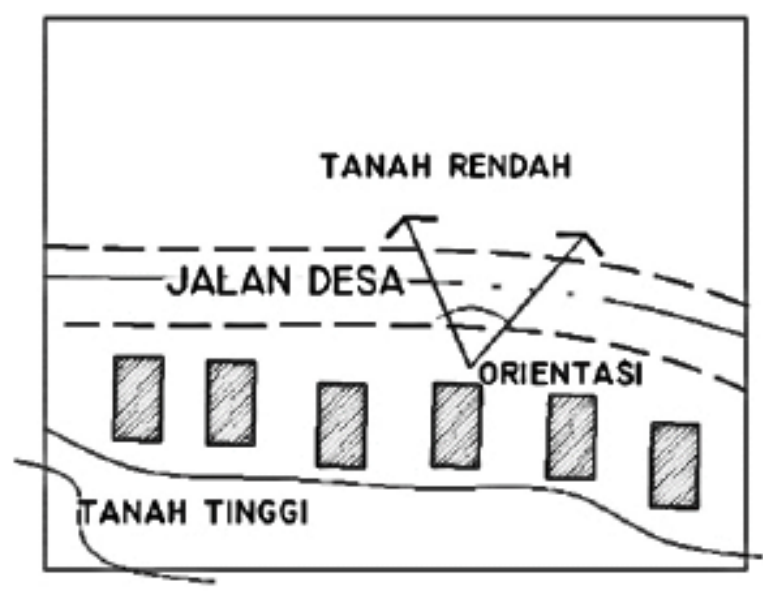

Orientasi ke arah jalan (tanah yang lebih rendah)

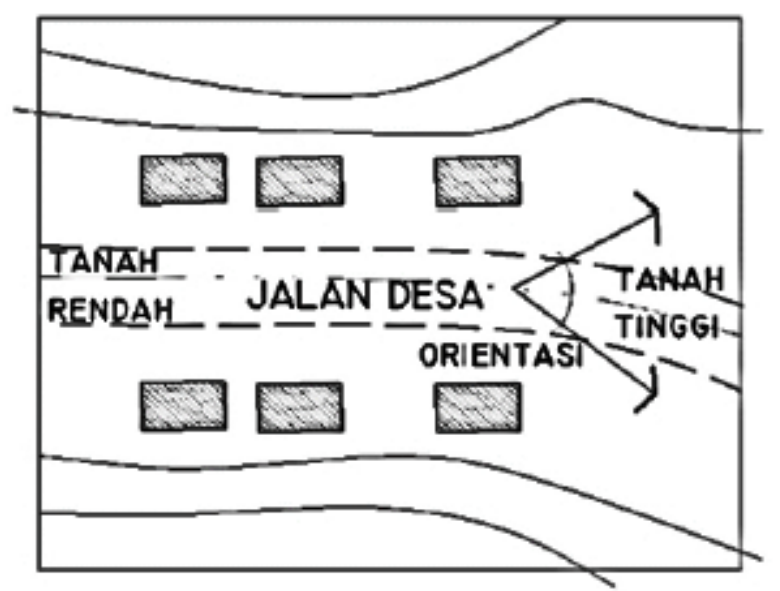

Orientasi ke arah tanah yang lebih tinggi

Gambar 10. Orientasi Rumah Berdasarkan Pertimbangan Topografi Tanah Perbukitan dan Jalan Sumber: Hasil Analisa, 2015 


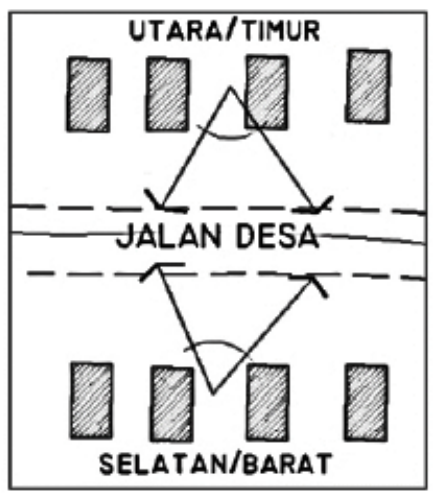

Orientasi ke arah jalan dapat menghadap ke arah mana saja sesuai dengan kondisi jalan

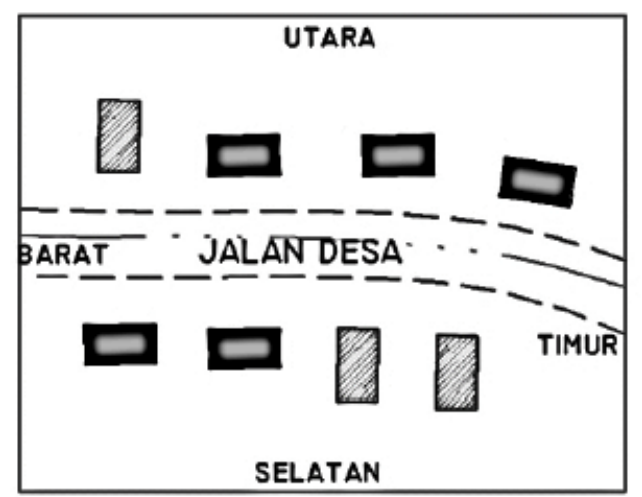

Orientasi gabungan antara yang menghadap ke jalan dan yang mempertimbangkan arah terbaik (timur-barat)

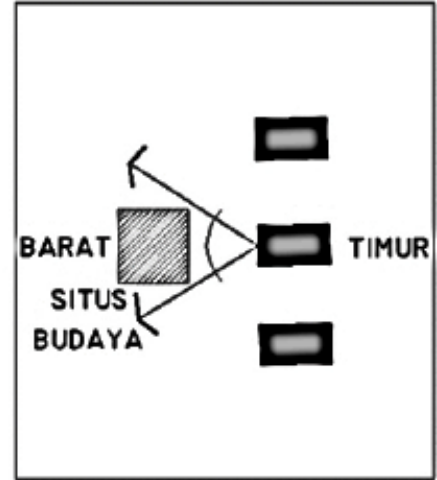

Orientasi yang menghadap ke arah benda budaya yang disakralkan

Gambar 11. Orientasi Rumah Berdasarkan pada Topografi Tanah yang Datar Sumber: Hasil Analisa, 2015

Karakteristik orientasi rumah tradisional Bugis yang ada di Dusun Kajuara secara umum mempertimbang arah orientasi terbaik timur barat, menghadap ke arah tanah yang lebih tinggi atau perbukitan dan mempertimbangkan orientasinya terhadap jalan untuk mempermudah aksesibilitas. Orientasi terhadap penjuru mata angin dapat menghadap ke arah mana saja, menyesuaikan dengan kondisi jalan dan topografi. Jalan di dusun ini melintas dari timur ke barat, sehingga sebagian besar rumah yang berorientasi ke jalan akan menghadap ke arah selatan atau utara. Tipe bola mangolo (menghadap jalan) lebih banyak ditemukan di kondisi topografi yang datar (RT 3, 4, dan 5), sedangkan tipe bola mpare lebih banyak ditemukan pada kondisi topografi perbukitan yaitu di RT 1 (La' gangka dan Paccanring) dan RT 2 (Kampiri). Berikut ini hasil perbandingan karakteristik orientasi pada masing-masing kelompok permukiman (Tabel 1).

Tabel 1. Karakteristik Orientasi Bola Ugi pada Kelompok Permukiman

\begin{tabular}{lll}
\hline No. & Kelompok permukiman & Karakteristik orientasi \\
\hline 1 & RT 1 (Paccanring \& La' gangka) & $\begin{array}{l}\text { Kedua wilayah ini memiliki karakter orientasi } \\
\text { yang sangat beragam, yaitu berpatokan pada } \\
\text { perbukitan, arah orientasi yang dianggap baik, } \\
\text { dan sirkulasi jalan. }\end{array}$ \\
\hline 2 & RT 2 (Kampiri) & $\begin{array}{l}\text { Sebagian besar rumah tradisional Bugis yang ada } \\
\text { di ketiga wilayah ini secara keseluruhan } \\
\text { menjadikan sirkulasi jalan sebagai pusat orientasi } \\
\text { rumah dan pertimbangan arah rumah yang baik. }\end{array}$ \\
\hline 3 & RT 3 (Cilellang) & RT 3 (Kajuara/Lalengbata \\
\end{tabular}

Sumber: Hasil Analisa, 2015

Berdasarkan pada hasil observasi lapangan, wawancara, dan pembahasan karakteristik orientasi rumah tradisional Bugis yang ada di Dusun Kajuara, maka muncul beberapa patokan arah orientasi bola ugi yang dijadikan pertimbangan acuan arah hadap rumah, yaitu sebagai berikut: (a). Rumah yang menghadap ke arah tanah yang lebih tinggi, hal ini terkait dengan kepercayaan mengarahkan rumah ke dunia atas sebagai tempat tertinggi dalam tingkatan Ketuhanan. Bagi rumah yang berada pada topografi yang berkontur sebaiknya meletakkan bagian belakang rumah pada topografi tanah yang lebih rendah dan bagian depan rumah yang diibaratkan sebagai kepala harus diletakkan pada posisi yang lebih tinggi, (b). Rumah yang menjadikan jalan sebagai pusat orientasi, 
jenis ini mempertimbangkan faktor aksesibilitas sirkulasi jalan, (c). Rumah yang mempertimbangkan arah orientasi yang dianggap baik (timur/barat), jenis ini mempertimbangkan arah orientasi rumah yang dianggap baik, yaitu barat yang bernilai keselamatan dan timur bernilai rezeki, sehingga meskipun berada pada kondisi tanah yang datar dan dekat dengan jalan utama jenis rumah ini menjadikan arah orientasi yang baik sebagai pertimbangan utama, dan (d). Rumah yang menghadap ke arah situs budaya, jenis ini tidak terkait pada unsur kepercayaan, namun merupakan bentuk penghargaan dan perlindungan terhadap situs budaya yang bersejarah, yang telah menjadi bagian dari adat masyarakat setempat.

Arah orientasi rumah yang menghadap ke tanah yang lebih tinggi/perbukitan dan yang berdasarkan pertimbangan orientasi rumah yang baik merupakan bentuk penerapan anjuran terkait kepercayaan yang mengandung nilai dan makna tersendiri, seperti yang dijelaskan oleh sanro bola (dukun rumah) terkait dengan konsep orientasi rumah tradisional Bugis di Dusun Kajuara. Dengan adanya pertimbangan-pertimbangan acuan orientasi tersebut, maka karakteristik orientasi rumah tradisional Bugis di Dusun Kajuara memiliki hasil yang beragam.

\section{Kesimpulan}

Hasil penelitian menunjukkan bahwa dasar munculnya orientasi rumah tradisional Bugis bola ugi yang beragam pada permukiman tradisional Dusun Kajuara adalah terkait dengan konsep orientasi yang menganggap bahwa rumah dapat menghadap ke arah empat penjuru mata angin, dengan arah terbaik menghadap timur dan barat dengan mempertimbangkan kondisi topografi letak rumah berada.

Rumah yang berada pada topografi perbukitan umumnya akan berorientasi ke arah tanah yang lebih tinggi seperti yang terjadi di wilayah RT 1 dan 2, sedangkan yang berada pada kondisi tanah datar secara umum berorientasi ke jalan, seperti yang terjadi pada RT3, 4, dan 5. Di antara kedua jenis wilayah tersebut, juga terdapat rumah yang mempertimbangkan arah orientasi yang baik terkait dengan kepercayaan adat, ataupun mengacu pada suatu hal yang disakralkan. Dengan adanya konsep orientasi yang dapat mengarah kesemua penjuru mata angin mengakibatkan masyarakat lebih mempertimbangkan orientasi rumah yang langsung menghadap ke jalan demi kemudahan aksesibiltas. Pertimbangan terhadap aturan konsep adat dan tradisi mengenai orientasi terbaik tidak terlalu di pertimbangkan lagi pada kelompok permukiman dengan topografi tanah yang datar.

Karakteristik orientasi berdasarkan wilayah dibagi menjadi dua, yaitu wilayah timur meliputi RT 5 (Kajuara dan Laleng Bata), 4 (Mappenrae), dan 3 (Cilellang) lebih mempertimbangkan orientasi yang langsung menghadap ke jalan dengan kondisi topografi tanahnya yang datar, dan wilayah barat dengan kondisi topografi tanah perbukitan meliputi RT 1 (Paccanring dan La' gangka) dan RT 2 (Kampiri) masih mempertimbangkan aturan adat dan tradisi yang terlihat dari pemilihan orientasi terbaik (timur-barat) ataupun ke arah tanah yang lebih tinggi, meskipun terdapat beberapa rumah yang menjadikan jalan sebagai pusat orientasi.

\section{Daftar Pustaka}

Hasan, \& Prabowo. (2002). Perubahan Bentuk dan Fungsi Arsitektur Tradisional Bugis di Kawasan Pesisir Kamal Muara, Jakarta Utara. International Symposium 'Building Research and the Sustainability of the Built Environment in the Tropics' Universitas Tarumanegara.

Idawarni. (2011). Penentuan Arah dan Letak Permukiman dan Rumah Tinggal Kaitannya dengan Kosmologi, Studi Kasus: Kampung Kanarea, Kecamatan Bajeng Gowa Sulawesi Selatan. Local Wisdom-Jurnal Ilmiah Online, ISSN: 20863764. Volume: III, Nomor: 1, Hal: 09-18.

Mithen \& Onesimus. (2003). Arsitektur Tradisional Toraja Merupakan Ekspresi dari Aluk Todolo. Jurnal Penelitian Enjiniring Vol.9 No.3 September-Desember 2003 Hal. 300-308

Morrel, Elizabeth. (2005). Simbolisme, Ruang, dan Tatanan Sosial dalam Tapak-Tapak Waktu Kebudayaan, Sejarah, dan Kehidupan Sosial di Sulawesi Selatan. Inninnawa: Makassar. 
Nurjannah \& Anisa. (2010). Pola Permukiman Bugis di Kendari. NALARs Volume 9 Nomor 2 Juli 2010:139-146

Sumalyo. (2001). Kosmologi Dalam Arsitektur Toraja. Dimensi Teknik Arsitektur Vol. 29, No. 1, Juli 2001: $64-74$

Wikantiri, Veronika \& Marwah. (2011). Faktor Penentu Orientasi Rumah Di Permukiman Nelayan Dusun Salarang Kabupaten Maros. Prosiding Hasil Penelitian Fakultas Teknik Universitas Hasanuddin, Makassar. 